\title{
Missiology: Rise, demise and future at the university
}

NGTT DEEL 55, NR 3 \& 4, 2014

\section{Verster, Pieter}

University of the Free State

\begin{abstract}
Although a latecomer as discipline, missiology had an impressive rise in the history of theology. Gustav Warneck's "Evangelische Missionslehre (18971903)" resulted in missiology being regarded as an extremely influential discipline. This was not at all strange as Christian mission was a worldwide endeavour and accepted as the most important calling of the church. Throughout the 1900s missiology and missiological conferences continued to be the centre of theological discussions. With the political emancipation of Africa and the East, the whole concept of missions was challenged and this led to the demise of missiology as a discipline at universities. Influential missiologists, such as Johannes Verkuyl and David Bosch, published works of high theological value, but it seemed as if sociological, cultural and interreligious studies displaced missiology at university. Many seminaries are still putting up a brave fight to save missiology, but at university level it seems that classical missiology as discipline is being displaced. The future of missiology must, however, not be regarded as obsolete, but rather as an irreplaceable part of theology and faith.
\end{abstract}

\section{KEYWORDS}

Mission, Missiology, University, Future, Re-establish

\section{TREFWOORDE}

Sending, Sendingwetenskap, Universiteit, Toekoms, Herbevestig

\section{CONTACT DETAILS}

Prof Pieter Verster

Head Department of Missiology, University of the Free State

versterp@ufs.ac.za

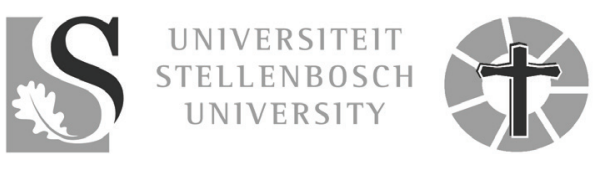




\section{INTRODUCTION}

Although a latecomer as discipline, missiology had an impressive rise in the history of theology. In the $16^{\text {th }}$ century, Voetius mentioned the threefold goal of missions as Conversio gentilium, Plantatio ecclessiae and Gloria et manifestatio gratia Dei. Voetius is regarded as the father of the scientific study of missiology in the protestant world (Kritzinger et al, 1994:1). The exponential rise of mission in the Western world initiated scientific study of missiology. As a discipline at universities in the West, missiology not only received much attention but was also held in high regard. This changed radically when mission and missiology were regarded as unsuitable disciplines for a modern university. Mission and missiology were judged from a perspective of exclusivism which was not the liberal democratic view held by the modern university.

\section{RISE OF MISSIOLOGY AS DISCIPLINE}

John Breckenridge became the first Protestant professor of missions at Princeton Theological Seminary in 1835. According to Steffen (2003:138), establishing this chair for pastoral theology and missionary instruction initiated the scientific study of missiology. The Seminary was founded in 1811 to not only service pastors, but also train missionaries. However, it is generally accepted that Gustav Warneck was the first to chair missiology at the University of Halle in 1897. With his inaugural address entitled "Missions' right to citizenship in the organism of theological science," he established missiology as an academic discipline (Steffen, 2003:138).

Gustav Warneck's “Evangelische Missionslehre (1897-1903)" (Verkuyl, 1987:13) resulted in missiology being regarded as an extremely influential discipline. Although Hoekendijk challenged many of Warneck's ideas, Verkuyl (1987:13) states that no one can discount his importance in the academic study of missiology. By the twentieth century, missiology related to practical theology and church history and could be included in it in the seminary curriculum (Steffen, 2003:138). Eventually it was accepted that it had established its own department.

Missiology received much attention at tertiary level. This was not at all strange as Christian mission was a worldwide endeavour and accepted as the most important calling of the church. During the 1900s, missiology and missiological conferences continued to be the centre of theological discussions. The rise of missiology was impressive. It was regarded as part of theological studies - even more so, as the prince of theological studies. The massive influence of missiology was clear at conferences on mission. Edinburgh 1910 was pivotal in this regard. Missiologists played an important role in explaining, defining and discussing the future of the church in the 
world. Even after the First World War, and for some time after the Second World War, missiologists played an important role in leading the discussion on the role of the church in the Western world, which was becoming more secular. In the past, the definition of missions and missiology was much clearer. Discussion on the premises of missiology was unnecessary. JH Bavinck became an influential Professor of missiology at the Free Reformed University of Amsterdam in 1939 (Verkuyl 1978:14). In the United States of America several professors, such as KS Latourette, raised the level of higher education in mission (Verkuyl, 1978:16). Mission was to bring the glorious redemption of God to the whole world, proclaiming the kingdom of God and Jesus' salvation. This was challenged as theological insights developed.

\section{DISCIPLINE OF MISSIOLOGY}

Missiology deals comprehensively with mission. Bosch (1991:8) describes the Christian faith as intrinsically missionary. In this regard the definition of mission becomes very important. Definitions have fluctuated between solely emphasising conversion to viewing social regeneration as the essence throughout history.

Steffen (2003:132) argues that "Mission refers to all that God wishes to accomplish in the world so that He is glorified and God's kingdom expands universally and comprehensively (missio Dei). Mission serves as God's overarching vision statement that influences all short- and long-term activities and resources, inside and outside the church, that take place in heaven and on earth." Wright (2008:29) explains that mission is thoroughly biblical. "Mission is what the Bible is all about; we could as meaningfully talk of the missional basis of the Bible as of the biblical basis of mission."

Bosch (1991:9) explains that the relation between God and the world has huge implications for mission. "Christian mission gives expression to the dynamic relationship between God and the world, particularly as this was portrayed, first, in the story of the covenant people of Israel and then, supremely, in the birth, life, death, resurrection, and exaltation of Jesus of Nazareth." A more holistic view is accepted currently, which discusses the fullness of God's involvement in human history and the implications of that involvement comprehensively. According to Kritzinger, et al (1994:36-39) the holistic approach includes the aspects of the church's task as kerygma (proclamation), diakonia (ministry of service), and koinonia (communion or fellowship). Leiturgia (worship) and marturia (witness) are also included.

Mission must be regarded as a comprehensive aspect of the proclamation of the gospel. It is intrinsically bound to glorifying Christ. It should always proclaim that Christ is Lord. This means that mission has evangelism as its central focus, from 
where the fullness of the gospel is proclaimed in every aspect of life. The church is the vehicle of this proclamation. Mission can, therefore, never be limited to one aspect, but should always include the comprehensive fullness of life from the perspective of salvation in Christ.

When mission is studied scientifically, missiology as discipline should be deliberated. Verkuyl (1978:5) defines missiology as "... the study of the salvation activities of the Father, Son, and Holy Spirit throughout the world geared toward bringing the Kingdom of God into existence." The what, why, how, who and when of mission are discussed and evaluated. The radical implication of the missio Dei is the understanding of mission. Therefore, missiology is regarded as dealing with God's mission and the way it is delivered in the missio ecclessiae (the mission of the church) and in the missiones humanitatis (the mission of and to the humanity). The who of mission then changes from the person or group involved, to God's mission. God is regarded as the primary source of missions. Missiology thus deals with this radical implication of the missio Trinitatis. Jongeneel (1991:60) refers to the development from the Roman Catholic missiology concerning the Trinitarian implications of mission as missio Dei, God the creator, getting involved in His own creation from whom He was rejected by His own. Mission is viewed as the Trinitarian act of God, with the implication that God the Father, Son and Holy Spirit is involved in mission. Missiology initiated a profound theological discipline. However, the what, and how, of mission also have historical, sociological, anthropological and cultural implications. These subjects should nonetheless be approached in a theological way from the perspective of the missio Dei or missio Trinitatis. The way in which mission was conducted in the past and the way in which it should now be conducted, should be discussed.

Missiology deals with missions. Steffen (2003:137) aptly describes the task of missiology. "In the educational setting, missiology is an academic discipline that describes, analyses, interprets, and practices global mission activities (whether assisted or unassisted by missionaries) expressed in society through 'word and deed.' Missiology researches the positive and negative effects of the global Christian movement expressed through the planting, development, and multiplication of holistic communities of faith. Its interest lies in mission, missions, missionaries, and movements."

Missiology is, therefore, a comprehensive theological discipline dealing with God's involvement in the world to redeem His creation. It should always be approached from the perspective of the Trinitarian salvation of the world as missio Trinitatis. Missiology should scientifically explain the fullness of the proclamation that Jesus is Lord. Missiology is thus irrevocably part of the theological deliberation of the gospel. 
Missiology inspires the church to become more obedient in her radical encounter with the world around her. Missiology deals with the Word of God, but also with the world. No stone should be left untouched in studying the effect of the gospel in the world. Missiology has practical implications. The vehicles of proclamation are inspired by it. Missiology is, therefore, essential to the church and theology as such.

\section{DEMISE OF MISSIOLOGY AS DISCIPLINE}

The political emancipation of Africa and the East challenged the concept of missions. This led to the demise of missiology as a discipline at universities. Questions were asked about the way in which mission was conducted, and the link between mission and colonialism. Once the heroes of the world, missionaries now became the villains. Missiology, once regarded as the prince among theological disciplines, now had to struggle to remain part of the theological scope. Secularism in the West also challenged the concept of traditional missiology. Bosch (1991:4) explains: "Rather, what has unfolded in theological and missionary circles during the last decades is the result of a fundamental paradigm shift, not only in mission or theology, but in the experience and thinking of the whole world." Although interdisciplinary study of religion remained acceptable on the level of general science, the Christian faith as such was judged as inconclusive and obsolete. Influential missiologists such as Johannes Verkuyl (1978), Johannes Jongeneel (1991), David Bosch (1991), Charles van Engen (1996) and Bevans and Schroeder (2006) published works of high theological value, but it seemed as if sociological, cultural and interreligious studies displaced missiology at tertiary level. Verkuyl (1978:16) refers to the fact that the trend in the USA in the 1970s was to absorb missiology into the course in ecumenism or history of religions. Even though many seminaries are still putting up a brave fight to save missiology, it seems that classical missiology, as discipline, is being displaced at tertiary level.

In a seminal discussion on the rise and collapse of missiology at the Boston University, Robert (1989:197) states that missiology had declined in the late 1960s and 1970s. This was also the case at universities such as Union-Columbia and the University of Chicago, which have extensive dissertation production. In 1958, with the division of the Graduate Department of Religious Studies and the Divinity School at Yale University, missiology was phased out of the doctoral programme, which made it virtually impossible to do doctoral work on mission. The trend would have been even worse if professors of Missiology had not continued their work at universityrelated seminaries in the sixties and seventies, and did not retire early during that period. Robert (1989:197-198) explains that this collapse results from the historic connection between missions and world religions becoming a liability. The reason 
was that, by the 1970s, university faculties no longer believed in the exclusive claims of Christianity. Study of world religions had also increasingly migrated into liberal arts faculties. Student activism of the late 1960s was another reason why mission study collapsed at Boston University (Robert, 1989:198). During the earlier student volunteer era and the Student Christian Movement era, student activism had a different influence, but in 1967 student activism centred on eliminating mission study.

Robert (1989:198) argues, however, that this was not the end of missiology. Even though mission study was collapsing at Boston University, the School of World Mission at Fuller Theological Seminary opened its doors at the same time (1965). World evangelism had led to a new thrust, which rivalled that of the late nineteenth century. There was an evangelistic thrust at Boston in the 1890s - 1920s. It had moved to Fuller, the Trinity Evangelical Divinity School, Asbury Theological Seminary's E. Stanley Jones School of World Mission and Evangelism, and other more specialised programmes of mission education (Robert, 1989:198). Robert (1989:198ff.) explains that globalisation is a lifeline for mission studies at Boston. An increasing number of international students attend the Boston University to do doctorates in missiology. They want to study and analyse the histories of their own forms of Christianity. However, Robert (1989:198) writes, "As missiologists, we must be careful that the broad globalization movement in the seminaries is not a Trojan horse. Globalization is bringing new prestige and even money to mission programs in the university setting. But it is not itself mission education. Just as world religions and sociology once seemed to be the perfect vehicle to carry mission study in the university, so globalization might one day find that mission is not a necessary part of its agenda. The world churches have just as much potential as the Western churches to become complacent about mission."

Cognisance must therefore be taken of the ambivalent situation of mission and missiology. While many institutions in the West are inclined to regard mission as obsolete, there are those pursuing its radical value for church and society. In this regard, the following should be taken into consideration: While mission is challenged by secular Christians and secular institutions as unacceptable in the new dispensation, there are many evangelical Christians and theologians emphasising its unconditional worth; while at some universities in the West missiology has been displaced by cultural studies, other institutions have developed it as an essential part of the curriculum; and while most no longer regard mission and missiology in the same way as in the $19^{\text {th }}$ century, it still has to be evaluated in the light of the gospel. This aspect needs further attention. 
In the South African environment, missiology was a highly respected discipline within the faculties of theology. Especially faculties of theology, educating ministers of the Dutch Reformed Church, held missiology in high esteem. State universities acknowledged theology as discipline at these universities. With the advent of the new dispensation in South Africa in 1994, the situation became precarious. While missiology is still taught at some universities' faculties of theology, it is constantly under threat to realign its premises. At some universities missiology became part of practical theology. Seminaries such as the Southern African Theological Seminary (SATS), however, still regard missiology as highly relevant.

\section{FUTURE OF MISSIOLOGY}

\subsection{Neutral university}

Missiology is challenged at universities because of its radical stance, namely that Christ is Lord. It is, therefore, necessary to discuss the aspect of the neutral university. A discipline such as missiology would, by definition, not be welcome at the neutral university if unconditional neutrality were established as being beyond discussion. The concept of the neutral university is discussed first.

Lombaard (2011:50) believes the essence of a university to be a community of scholars. He explains the basic characteristics of a university as universality, diversity, community service, and academic freedom. He warns against excluding religion from these premises, as it made no sense in the academic pursuit of knowledge (Lombaard, 2011:60). From a Christian, and specifically a Reformed philosophical perspective, Strauss (1990:128-129) argues that the university should be viewed from two perspectives. The university organisation (grounding) and the academic project (qualification) in the process of the scientific endeavour, seek the cultivation of knowledge from a certain definite starting point. In Strauss' case (1990:128-129), this perspective is the Christian reformed philosophical perspective. The university functions inevitably from its structural essence in the realm of the faith aspect. It is, therefore, impossible, according to Strauss (1990:129), to separate a certain scientific viewpoint from the mission of the university and the so-called neutral university, therefore, remains impossible.

The argument that missiology has to be regarded as unacceptable at the neutral university received much attention. The neutral university has no place for specific Christian views, especially if they are proclaimed as the truth to be followed and accepted. The question of neutrality immediately comes to mind. The liberal humanistic university is clearly not neutral at all. Many premises from a specific 
philosophical background influence the scientific endeavour of the neutral university, making it susceptible to all kinds of very un-neutral premises. Rationality, as the premise of the university, needs to be challenged. With the rise of postmodernism, some scientists accept that neutral science is not possible, but the Western university is still linked to the premise of rationality as a neutral view.

Macdonald, (2010:1019) warns against the sectarians' claim that only theology is capable of properly integrating and relating the university's disparate disciplines. $\mathrm{He}$ states, however, that not all sectarians hold to the claim that theology is the "queen of the sciences" in the same way. He explains that theology is not only "queen" but also "servant," "since it seeks to relate, challenge, educate, but also respect those disciplines as unique, individual spheres of intellectual inquiry." Macdonald (2010:1020) chooses the term "sibling" which is perhaps a more adequate term to describe its relationship with the other disciplines in the secular university. "Theology helps in understanding disciplines better: disciplines such as philosophy, art history, literature, history, politics, and even physics, which deals with intellectual questions for which at least some metaphysical speculation is required (e.g., the causal origins of the universe). Theology should also press the secular university and its various disciplines to overcome any inveterate tendency toward fragmentation and the compartmentalisation of knowledge and truth seeking." He continues: "But on the model I am proposing, the vital connection between the academic study of theology and its lived practice in the Church is embedded in the tradition-dependent, authority-based theological reasoning in which all members of the secular academy can participate; and more than that, is embodied in actual theological practitioners who inhabit the secular university and engage in such reasoning from the explicit standpoint of Christian faith."

D'Costa (2005:148) puts up a brave fight against Dawkins and Weibe for the right of theology to be accepted at state university level. He challenges the primes of science of the neutral secular university and shows how complex the process of secularism is and how modernity dictated the methods of studying theology, especially embodied in Berlin. He proposes a theological understanding of religions and how the proper horizon of theology could be embraced, namely God's whole creation (2005:153). $\mathrm{He}$ calls for specific starting points to be accepted and proposed. These should be labelled correctly, allowed to flourish and to interact with others. This could lead to a specific Christian university.

Van de Beek (2012:86) is of the opinion that the concept of filled neutrality, as an idea that leads to a positive engagement with the public university and theology, must be proposed. Provision is then made for all religions without rejecting some. However, on the other hand, they are not assessed by external criteria but by their 
own internal critical power. This openness leads to the acceptance of academic criteria, but also to the right of religion and theology as such, and missiology. I would add to present their intrinsic values fully at the university.

It must be clear that the university, while seeking universal knowledge, can never be completely neutral. Even today, faith has such a massive influence in the world that it cannot be disregarded. While guarding against sectarianism the university should seek to be true to the endeavour of seeking total knowledge and accepting the potential different premises. It is impossible to separate faith and university and much better to state scientific views in the mission of the university. Missiology should not be regarded as dangerous to the essence of the scientific endeavours of the university. Theology is as acceptable a discipline as any other, and missiology is inextricably part of theology. This aspect should receive attention.

\subsection{University and universal knowledge}

The university has to deal with universal knowledge. De Freitas (2011:37) refers to the fact that the public university cannot separate itself from beliefs and belief systems. By accepting this view, it should be noted that deciding beforehand that knowledge has to be of a certain kind, excludes a real scientific encounter. Although it must be acknowledged that not all knowledge can be taught, researched and developed at all universities, it is unscientific to exclude certain aspects of knowledge and to snub a university if it does accommodate missiology.

Newman (1996:409) suggests a specific Christian approach. "My goal is to provide an alternative model, one that moves beyond faith versus knowledge and understands that faith commitments, informed by a school's particular religious heritage, are not peripheral and extra-curricular, but integral to the intellectual task of the Christian university or college."

What is the raison dêtre of a university? What kind of knowledge should be developed? The university has the right to pursue specific knowledge and to state openly that the specific university, even a public university, has a definite scientific view as not all knowledge can be evaluated. However, certain knowledge cannot, per se, be disregarded. The university must always be attentive to the fact that the knowledge it displays should be in accordance with certain values.

These values cannot be achieved by rejecting the values that, in time, become part of the university from a theological perspective. The only true university is not the neutral university. 
Values, such as integrity in research, the value of the human person, respect for nature and the environment, and reaching towards a better future have a significant theological background. Missiology should also empower the university to understand the God-given task to spread the gospel of Christ for the full implication of the truth of God.

Brand (2011:22) argues that theology, and even confessional theology, has an acceptable place at the public university. The critical and constructive aim of theology is as acceptable as comparative religion. But, theology that takes the position of truth and validity of religious beliefs implies that it is separate from religious studies, history of religions and comparative religion. He explains that theology is faith seeking understanding, fides quaerens intellectum, and not merely seeking to understand faith. Brand (2011:24) challenges the tendency of some theologians to change their approach to general appreciation of religion instead of critical and constructive engagement in theology.

Van Niekerk (2011:122) writes "Theology as a discipline practised at (also) modern universities is legitimised by the practical interest (in Habermas's sense, as explained earlier) as ground for a special, legitimate kind of knowledge. Theology is an expression of the conversation of humankind in which we, via an intersubjective dialogue, reach consensus on the values that render our lives in the world meaningful."

Wethmar (2012:80-81) argues convincingly that the confessionality of the Reformed position is reconcilable with the universities' context of academic freedom if is it not equated with legalism. But, in a reformed context, the confession has its validity in the way in which the Holy Scripture brings its authority to bear in new contexts in a dynamic, doxological and spiritual train of events in which the liberation and firmness of faith is reconciled with open-mindedness.

Van der Walt (1994:570-571), a prominent Christian philosophical scholar from South Africa, argues that it is not possible to separate a Christian worldview from one's scientific and academic endeavours. If this is done it leads to dualism. One cannot separate faith and the reality around us. Secular neutralism does not take into account that beliefs are also part of the neutral viewpoint. Van der Walt (1994:571) explains that neutrality is also a principle that can be challenged by exactly the same view it holds. According to him, the whole concept of neutrality is unacceptable because a person can never be neutral and the God of the Bible requires a clear confession regarding Him. Van der Walt (1994:572) writes: “The Christian scholar makes a clear distinction between objectivity and neutrality in scientific activity: the former is essential, but the latter is impossible." He (1994:575) then argues for 
the central, encompassing role of Christian faith in all human activity, all science. Like salt and yeast, it must permeate every science. Christian scholarship should be marked by fidelity to God's revelation. According to Van der Walt, theology has a different approach from philosophy: philosophy studies the totality of creation in the light of scriptural revelation, while theology studies God's scriptural revelation in the light of His creation (all revelation) (1994:580).

It is, therefore, impossible to seek universal knowledge without allowing for a deep theological stance. It would not be true to the essential meaning of seeking universal knowledge if theology is disregarded. Missiology at the university can lead to indepth and intrinsic discussions on the aspect of faith in life in general. It needs to take its place as essential discipline in theological discussion, because of its stance in the proclamation of the Word. Theology at university level is, thus, essential to allow for the full spectrum of life. This scientific discussion is necessary even at the neutral university. Naturally, not all universities would have such departments or faculties, but it must be clear that it cannot be dismissed out of hand.

\subsection{Missiology and the future of theology}

Missiology is an intrinsic part of theology. It has to be acknowledged as part of the university. As theological subject it needs to be discussed and evaluated. Theology would be extremely poorer if missiology is not taught as part of the theological disciplines. Kirk (1999:11) states convincingly that without mission, there can be no theology, and no theology, which is not missionary. This being so, missiology must be accepted as driving theological knowledge to the full.

\subsection{New implications}

The future of missiology must, therefore, not be regarded as obsolete, but rather as an irreplaceable part of theology and faith. It is clear that missiology had to adapt to newer insights in theology, but it still influences how Christian faith is regarded in the world. Missiology can, indeed, steer theology on the right path in a time when theology is very uncertain of its own way forward.

\subsubsection{Full attention needed for definition}

It is clear that the definitions of mission and missiology need renewed attention. Mission should be regarded as holistic, influencing all aspects of the community by spreading the gospel, namely evangelism, proclamation, intercultural relations and religious dialogue, social regeneration and ethical renewal. The debate on whether missiology should still discuss conversion and renewal of faith seems relevant. However, it is of the utmost importance to evaluate the evangelical emphasis on 
salvation in deciding on the definition of mission and the task of missiology. The challenge is to view missiology as holistic, without becoming so encompassed in theology that the essence of missiology is lost. Missiology has the essential task of leading the church to understand the fullness of mission in a world yearning for the full message of the gospel. Therefore, missiology has to find a real, intrinsic essence.

\subsubsection{Influence on the faith of Christians}

It remains important to regard mission as an intrinsic part of faith as it is essential to understand that the future of the church remains part of the expansion of the Christian faith. Faith brings one in a relationship with God in Christ. Faith is essential for the church to flourish. Mission and faith are related.

In this regard Venter (2012:66) emphasises transcendence as essential for theological discussion. "The contribution theology can make in the public sphere is to remain true to the heart of religion: Transcendence. Theology should seek an ever-increasing movement towards the Mystery of the world. For Christian theology, this is a journey to a deeper appreciation of the fullness of the triune God, and to a more creative understanding of all of life in this Love."

Mission is deeply and radically related to the aspect of transcendence. It is mission that empowers the church to bring the message of the transcended God to a world in which secularism seems to be rampant.

\subsubsection{Mission and Church}

Mission as a holistic endeavour encompasses all aspects of life. From this perspective, faith is also the reply of the church to the cry of the world. Missiology at the public university should pay attention to the responses of the church to the questions of the world. The relation of theology, church, faith and university calls for intensive discussion. Barth (1969:ix) has the notion of theology in service of the church (Church Dogmatics). Theology at university level serves the scientific community, the church and the world.

\subsubsection{Future of missions}

The future of mission and the way in which missiology should serve the church and science lie in the relationship with the living God. If missiology breaks out of the confinement of judgemental mission to holistic empowering mission, new possibilities open up. Wonderful new possibilities arise if the church regards her to be the vanguard of the proclamation that Christ is still the Lord. Whole communities can be empowered by the message of life brought by mission and explained missiologically. 


\subsubsection{Future of the church}

The future of the church lies with obediently following God's will. The church needs mission and mission needs missiology as guidance in a challenging world. The future of the church relies on a strong view on the missions of the church. Where the church is on the back foot, it can be empowered to realise her calling anew when mission is at the centre of her calling.

\subsubsection{Missiology at the public university}

Holistic missions in deep, insightful discussion on the task of spreading the Gospel in all aspects should remain essential to the university. Why? Because it is impossible to separate it from theology and theology remains an essential scientific subject.

Steffen (2003:148) sees a role for missiology at the different institutions of education, such as seminaries, Bible colleges and institutes, local churches, Christian universities, or separate schools that focus specifically on missions, but are of the opinion that the Christian university seems to relate best to the multi-disciplined, integrative nature of missiology. He is of the opinion that the safest for missio Dei seems to be a separate school within the university that focuses specifically on global missions.

Robert (1989:201) also sees a definite role for mission. “The most exciting possibilities for mission scholarship will occur when the university-related seminary enters into a symbiotic relationship with a more specifically missionary-oriented institution."

Missiology is such a rich discipline that it must not be relegated to the seminary alone. It can serve theology and the university in a wonderful way by showing the way of faith and Christian involvement in the world in need.

To accomplish this, missiology should revisit its roots as a deeply committed discipline by intensive biblical research about its methods and scope; seeking universal knowledge; evaluating its past and seeking the future from Scripture; being true to its Lord and Master Jesus Christ; and serving science and church by leading the way of service to Christ and the world.

\section{CONCLUSION}

In a secularised Western world, the church's premises need to be re-established. Mission should be an essential part of the discussion of the church's role in society. Missiology, as discipline, can guide the evaluation of mission's task in the world. Missiology remains essential as theological subject and should be regarded as irreplaceable. 


\section{BIBLIOGRAPHY}

Barth, K 1969. The doctrine of the Word of God. (Prolegomena to Church Dogmatics Vol. 1 Part1. (Translated by GT Thomson). Edinburgh: T\&T Clark.

Bevans, SB and Schroeder, RP 2006. Constants in context: A theology of mission for today. Maryknoll, NY: Orbis.

Bosch, DJ 1991. Transforming mission: Paradigm shifts in theology of mission. Maryknoll, NY: Orbis.

Brand, G 2011. "Is fides quaerens intellectum a scholarly enterprise? Some thoughts on confessional theology at a public university." In Venter, R (ed), Faith, religion and the public university. Acta Theologica Supplementum, 14:20-30.

D'Costa, G 2005. "On theologising theology within the secular university", Transformation 22(3):148-157. (AN:ATLA0001615879) (Accessed 21 August 2013.)

De Freitas, SA 2011. “The public university, religion, and a pluralist platform for communication." In Venter, R (ed), Faith, religion and the public university. Acta Theologica Supplementum, 14:31-48.

Jongeneel, JAB 1991. Missiologie. II Missionaire theologie. 's-Gravenhage: Boekencentrum.

Kirk, JA 1999. What is missions? Theological explorations. London: Darton, Longman \& Todd.

Krtizinger, JJ, Meiring, PGJ and Saayman, WA 1994. On being witnesses. Halfway House: Orion.

Lombaard, C 2011. "Having faith in the university? Aspects of the relationship between religion and the university." In Venter, R (ed) Faith, religion and the public university. Acta Theologica Supplementum, 14:49-65.

Macdonald, PA 2010. "Studying Christian theology in the secular university", Journal of the American Academy of Religion, 78 (4): 991-1024. (AN: ATLA0001829988).

Newman, E 1996. "Beyond faith versus knowledge: Religious commitment in the academy", Perspectives in Religious Studies, 23, 4, pp 405-423, ATLA Religion Database with ATLASerials, EBSCOhost, viewed 13 August 2013. 
Robert, D 1989. "Mission study at the university-related seminary: The Boston University School of Theology as a case study", Missiology: An international review, Vol XVII, No. 2, April 1989:193-202.

Steffen, T 2003. "Missiology's journey for acceptance in the educational world", Missiology, 31, 131-153, ATLA Religion Database with ATLASerials, EBSCOhost, viewed 13 August 2013.

Strauss, DFM 1990. Die mens en sy wêreld. Bloemfontein: Tekskor.

Van de Beek, A 2012. "Theology at a public university." In Venter, R and Tolmie, F (eds), Transforming theological knowledge: essays on theology and the university after apartheid. Bloemfontein: Sun Press. 83-92.

Van der Walt, BJ 1994. The liberating message: A Christian worldview for Africa. Potchefstroom: PU for CHE.

Van Engen, C 1996. Mission on the way: Issues in mission theology. Grand Rapids. MI: Baker.

Van Niekerk, AA 2011. “Understanding theology as understanding." In Venter, R (ed), Faith, religion and the public university. Acta Theologica Supplementum 14:128-140.

Venter, R 2012. “Theology, the post-apartheid university and epistemological transformation: intimating the shape of the challenge." In Venter, $\mathrm{R}$ and Tolmie, F (eds), Transforming theological knowledge: Essays on theology and the university after apartheid. Bloemfontein: Sun Press. 45-72.

Venter, R and Tolmie, F (eds) 2012. Transforming theological knowledge: Essays on theology and the university after apartheid. Bloemfontein: Sun Press. 45-72.

Verkuyl, J 1978. Contemporary missiology: An introduction. (Translated by Dale Cooper). Grand Rapids, Michigan: Eerdmans.

Warneck, G 1897-1903. Evangelische Missionslehre: Ein missionstheoretischer Versuch. Gotha: F.A. Oerthes.

Wethmar, C 2012. "Theology and the university: Historical and contemporary perspectives." In Venter, R and Tolmie, F (eds), Transforming theological knowledge: Essays on theology and the university after apartheid. Bloemfontein: Sun Press. 73-82.

Wright, CJH 2008. The mission of God: Unlocking the Bible's grand narrative. Nottingham: IVP. 
